\title{
ФОРМИРОВАНИЕ МЕЖКУЛЬТУРНОЙ КОММУНИКАТИВНОЙ КОМПЕТЕНЦИИ В ПРОЦЕССЕ ОБУЧЕНИЯ ИНОСТРАННОМУ ЯЗЫКУ
}

\author{
Мартынова М.A. ${ }^{1}$

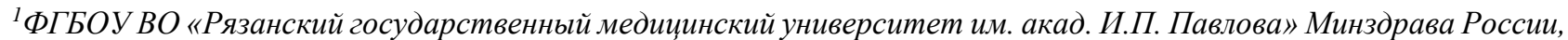 \\ Рязань, e-mail: marinamartynova81@gmail.com
}

В статье рассматривается актуальность проблемы формирования межкультурной коммуникативной компетенции у студентов медицинского вуза в процессе обучения иностранному языку. Подчёркивается значимость изучения иностранного языка в медицинском вузе как средства подготовки будущих специалистов медицинского профиля к профессиональной деятельности как в родной стране, так и за рубежом. Представлены результаты экспериментального исследования, направленного на выявление исходных специальных и общекультурных знаний по иностранному языку у обучающихся, а также выявление уровня мотивации у студентов медицинских вузов к изучению иностранного языка. Результаты экспериментального исследования показали недостаточный уровень знаний и вовлеченности будущих специалистов в данную проблему. Автор предлагает направления, реализация которых будет способствовать повышению уровня мотивации к приобретению знаний, умений и навыков в области межкультурной коммуникативной компетенции у будущих специалистов в процессе обучения иностранному языку. В статье делается вывод, что формирование межкультурной коммуникативной компетенции у студентов медицинского профиля должно осуществляться на основе применения технологий активизации и интенсификации учебной деятельности, таких как метод проектов, метод кейсов и ролевая игра.

Ключевые слова: межкультурная коммуникация, межкультурная коммуникативная компетенция, студентымедики, система здравоохранения.

\section{THE DEVELOPMENT OF INTERCULTURAL COMMUNICATIVE COMPETENCE IN TEACHING A FOREGN LANGUAGE}

\author{
Martynova M.A. ${ }^{1}$
}

${ }^{1}$ I.P. Pavlov Ryazan State Medical University, Ryazan, e-mail: martynovamarina81@gmail.com

The article focuses on the relevant issue of preparing medical students for intercultural communicative competence in teaching a foreign language. It emphasizes the significance of learning a foreign language at a medical university as a means of preparation future specialists for their professional activity both in their home country and abroad. The results of the empirical part of the study focus on medical students' foreign language knowledge and cultural background as well as the motivation to learn a foreign language. The results of the study revealed the insufficient level of students' foreign language knowledge and motivation to acquire language skills. The author offers suggestions on how to improve levels of English for future medical specialists and to encourage them to learn foreign languages in order to better prepare them for intercultural communications. This article concludes that development of intercultural communicative competence in future health care professionals should be carried out by a broad range of activities such as projects, case studies, and role playing.

Keywords: intercultural communication, intercultural communicative competence, medical students, public health.

Современный мир, стоя на пороге глобальной социальной и политической катастрофы, еще больше, чем раньше, нуждается в формировании международных, межгосударственных, межконфессиональных и профессиональных контактов. Резкий всплеск международных медицинских взаимодействий, произошедший за 2020 год, стал началом неотвратимой всеобщей интеграции в этой сфере. Таким образом, на первый план при обучении в медицинском вузе выходит формирование и воспитание конкурентной, культурно развитой личности, способной осуществлять деловое общение как на родном, так и иностранном языках 
[1]. На настоящий момент эти умения нужны для четкого взаимодействия перед лицом пандемии COVID-19.

Как пример, практика 2020 года показала высокую вовлеченность обучающихся в высших медицинских учреждениях в волонтерское движение. Студенты не только принимают участие в работе так называемых красных зон лечебных учреждений, но и помогают многонациональному населению, а также своим сокурсникам-иностранцам, не имеющим возможность выехать в родную страну, оставшись без привычного семейного, материального, культурного и языкового окружения.

Подготовить будущих специалистов к такому межкультурному взаимодействию актуальная задача для современного высшего медицинского образования. Современный врач не только должен владеть на высшем уровне своей специальностью, но и иметь достаточное знание иностранного языка для полного понимания ситуации в каждом конкретном случае заболевания, для пополнения багажа знаний, для активного и продуктивного общения с коллегами.

Таким образом, обращаясь к опыту пандемии, прочих медико-социальных катастроф, совершенно необходимым считаем продолжать исследовать проблему формирования и развития межкультурной компетенции у студентов-медиков.

Целью исследования является определение уровня готовности будущих специалистов к межкультурным контактам на примере студентов медицинских вузов. Задачей экспериментального исследования является анализ исходных специальных и общекультурных знаний по иностранному языку, а также мотивации учебно-познавательной деятельности к изучению иностранного языка.

\section{Материалы и методы исследования}

В качестве субъектов эксперимента были выбраны студенты четырёх учебных групп 2го курса по специальности «Лечебное дело», проходившие обучение на кафедре иностранных языков Рязанского государственного медицинского университета имени академика И.П. Павлова (ФГБОУ ВО «РязГМУ» Минздрава России). Всего в исследовании приняли участие 57 респондентов. Исследование проводилось в два этапа.

На первом этапе было предложено лексико-грамматическое тестирование с целью определения имеющегося когнитивного фонда студента-медика: полноты знаний, системности, осознанности знаний иностранного языка и особенностей культуры изучаемого языка.

Тесты включали в себя 20 вопросов с выбором одного правильного варианта из 4 предложенных и оценивались по пятибалльной системе. Тестирование было направлено на оценку комплекса специальных знаний по иностранному языку, который способствовал бы 
успешному развитию личностного потенциала будущих специалистов в профессиональной сфере и лучшей подготовленности студентов медицинского вуза к межкультурному диалогу в поликультурном пространстве. Кроме того, отслеживался уровень общей информированности студентов-медиков в области культуры, которая предполагает умение студентов медицинского профиля применять свои знания в области мировой и художественной культуры, социокультурные, страноведческие знания на занятиях по иностранному языку.

На втором этапе для определения исходного уровня познавательного интереса к изучению иностранного языка было проведено анкетирование участников исследования. Автором была разработана анкета, содержащая 7 вопросов, направленных на выявление уровня мотивации у студентов-медиков к изучению английского языка.

\section{Результаты исследования и их обсуждение}

По результатам тестирования, на начало года студенты-медики с высоким уровнем специальных знаний и общей информированности в области культуры составляли 7,0\%, со средним уровнем - 22,8\%, а с уровнем ниже среднего - 70,2\%.

Таким образом, результаты теста показали недостаточный уровень специальных знаний по иностранному языку у студентов-медиков, а также недостаточный уровень владения общекультурными и социальными знаниями. Что подтверждает необходимость проведения работы в данном направлении.

При анкетировании на первый вопрос анкеты - «Считаете ли Вы достаточным своё знание английского языка для будущей профессиональной деятельности?» - две трети опрошенных $(61,4 \%)$ ответили отрицательно и только $38,6 \%$ студентов ответили положительно.

Второй вопрос анкеты - «Считаете ли Вы необходимым изучение медицинской терминологии на английском языке?» - показал, что почти все студенты второго курса, участвующие в эксперименте $(98,2 \%)$, заинтересованы в изучении медицинской терминологии и только $1,8 \%$ опрошенных не считают это важным.

Третий вопрос - «Стремитесь ли Вы поддерживать беседу медико-ориентированной направленности на английском языке?» - выявляет нежелание будущих врачей вести коммуникацию на профессиональную тему. Лишь 8 человек $(14,0 \%)$ могут ответить на этот вопрос положительно. Можно сделать вывод, что изучение специализированного иностранного языка проходит в теоретической плоскости, без прямого контакта с носителями, так как нет возможности преодолеть языковой барьер.

Четвёртый вопрос - «Рассматриваете ли Вы дальнейшее использование английского языка для продвижения в профессиональной сфере?» - выявил большой процент положительных ответов $(77,1 \%$ - «да» и 22,9\% - «нет»), что говорит о желании студентов- 
медиков принимать участие в международных конференциях, ездить на стажировки за границу, обмениваться опытом с иностранными коллегами.

Пятый вопрос - «Читаете ли Вы научную литературу на английском языке в свете будущей профессии?» - показал слабое использование иностранного языка для чтения публикаций медицинской тематики. Только 10,5\% опрошенных ответили положительно и $89,5 \%$ ответили отрицательно.

Шестой и седьмой вопросы требовали развёрнутого ответа. Шестой вопрос - «Если не читаете научную литературу на английском языке, то почему?» - вытекает из четвёртого вопроса. Среди причин лидирует ответ «недостаточное знание иностранного языка» и «мало свободного времени».

При ответе на седьмой вопрос - «Что побуждает вас изучать английский язык в медицинском университете?» - студенты указывали следующие причины: желание читать художественную литературу и просматривать фильмы в оригинале, иметь возможность общаться с иноязычными друзьями, проходить контрольные точки на курсе иностранного языка. При этом изучение языка для его практического применения в рамках своей будущей работы стояло на последнем месте. Мы предполагаем, что в этом проявляется отсутствие понимания студентами места иностранного языка в своем постоянном профессиональном росте.

Данные, полученные в результате констатирующего эксперимента, приведены в таблице.

Результаты констатирующего эксперимента

\begin{tabular}{|l|l|l|l|c|}
\hline & \multicolumn{2}{|c|}{ Этап 1 (N=57) } & \multicolumn{2}{c|}{ Этап 2 (N=57) } \\
\hline Низкий (0-2 балла) & 40 чел. & $70,2 \%$ & 35 чел. & $61,4 \%$ \\
\hline Средний (3-4 балла) & 13 чел. & $22,8 \%$ & 16 чел. & $28,1 \%$ \\
\hline Высокий (5 баллов) & 4 чел. & $7,0 \%$ & 6 чел. & $10,5 \%$ \\
\hline
\end{tabular}

Анализ полученных данных позволил сделать вывод, что, несмотря на понимание необходимости студентами-медиками заниматься английским языком, общий уровень их мотивации к изучению иностранного языка недостаточен, так как обучающиеся на втором курсе еще не приобрели необходимый багаж специальных знаний.

Данные, полученные в результате констатирующего эксперимента, не позволяют дать положительную оценку знаниям и познавательной активности обучающихся, из чего можно сделать вывод о важности проведения работы по формированию межкультурной компетенции на занятиях по английскому языку. Необходимо таким образом построить учебный процесс, 
чтобы иностранный язык стал неотъемлемой частью менталитета специалиста в будущем, что будет способствовать успешной межкультурной и межнациональной коммуникации.

Для достижения этой цели мы предлагаем педагогические технологии на основе активизации и интенсификации учебной деятельности студентов, приоритетными из которых являются механизмы проблемного обучения, игровые технологии, метод проектов.

Наибольшего эффекта можно добиться, используя так называемые технологии проблемного обучения, когда обучающийся не просто решает некую задачу самостоятельно или в группе, но и анализирует весь процесс решения под контролем преподавателя. Наиболее заметным методом данной технологии является метод решения кейсов.

Кейс-метод ориентирован на обучающихся и основан на случаях из жизни или проблемах с контекстуальной информацией, при решении которых студенты применяют полученные знания, в результате чего приобретают опыт самостоятельной работы.

На занятиях по иностранному языку кейс-метод способствует развитию не только коммуникативных, но и необходимых для выполнения будущей профессиональной деятельности компетенций путём повышения мотивации к изучаемой дисциплине, развития умений (таких как анализ, оценка, синтез, постановка проблемы и принятие решения), стимулирования формирования умений устной и письменной коммуникации в межличностном общении и профессиональной деятельности, развития навыка критического, самостоятельного и нестандартного мышления при анализе выступлений других участников, а также способствует формированию навыков командной и самостоятельной работы, в том числе по сбору и обработке информации.

При проработке кейса следует придерживаться следующей структуры: 1) подготовка, во время которой происходит постановка целей и задач, выбирается используемая литература, составляется план проведения семинара, утверждается метод оценки формирования полученных умений; 2) установка, во время которой происходит ознакомление участников с условиями задачи, доносятся лимиты времени и условия игры, распределение студентов по группам; 3) работа с кейсом, во время которой происходит детальное знакомство участников с материалами кейса: чтение и анализ кейса, выполнение заданий, личное участие в обсуждении, проработка различных вариантов решения с анализом предлагаемой литературы под наблюдением ведущего; 4) финал обсуждения, когда происходит окончание работы в группах, выраженное в виде самостоятельной, как вариант - письменной работы; 5) оценка ведущим - происходит окончательный разбор обсуждения по определенным контрольным точкам, в том числе результатов письменной индивидуальной работы. Оценивается также и индивидуальный вклад участников в работу группы; 6) самостоятельная оценка результатов кейса, позволяющая обнаружить у участников способность к объективному суждению о 
проделанной работе как самого участника, так и его товарищей. Данный вид деятельности развивает у обучающихся умение работать с различными источниками информации, умение работать в группе и умение работать самостоятельно [2].

Следующей технологией предлагается игровая технология в процессе формирования познавательной активности у студентов высшей медицинской школы. Целью игры является формирование и развитие личности, обладающей высокоразвитой культурой.

Важным методом формирования межкультурной коммуникативной компетенции является ролевая игра, эффективная учебная технология, особенно для развития эмоционального восприятия, взаимопонимания и эмпатии, популярная среди преподавателей. Ролевая игра заключается в создании ситуаций, с которыми студентам-медикам придётся столкнуться в своей будущей профессии, где обучающиеся играют определённые роли. Также есть наблюдатели, которые следят за ходом игры и дают свою оценку в последующей дискуссии и анализе. Простой пример ролевой игры в сфере здравоохранения - это ситуация «врач - пациент» для разбора разных типов пациентов. Возможности игровых технологий настолько многообразны, что позволяют вовлечь в игровой процесс обучающихся с любыми индивидуальными особенностями [3].

Для преподавателя цель игры - это развитие навыков наблюдения, интерпретации и критического мышления студентов, навыков быстрого реагирования и принятия решения в нестандартных ситуациях, навыков командной работы в коллективе, эмпатии, открытости, уважения к другим культурам, коммуникативных навыков студентов в условиях межличностного и межкультурного общения в профессиональной сфере.

Ролевая игра в подготовке студентов-медиков должна строиться на нескольких принципах, приоритетные из которых следующие: принцип имитационного моделирования конкретных условий и динамики событий, принцип совместной деятельности, принцип диалогического общения.

Процесс проведения ролевой игры должен включать следующие этапы: 1) ознакомление с исходной информацией (определение учебных целей, задач и основных этапов работы, объединение студентов в малые группы, распределение ролей); 2) подготовка студентов к игре (чтение сценария и анализ игровой ситуации, изучение специальной литературы, подготовка ролей); 3 ) проведение игры (участники играют свои роли, происходит поиск совместного решения и его отстаивание, по результатам работы создается презентация каждой из подгрупп и ее демонстрация); 4) подведение итогов игры (оценка выводов, сделанных подгруппами, и игровой ситуации в целом).

Важным способом формирования межкультурной коммуникативной компетенции у студентов медицинского вуза является метод проектов. Метод проектов предполагает 
решение какой-либо проблемы, предусматривающей, с одной стороны, использование разнообразных методов, средств обучения, а с другой - интегрирование знаний, умений из различных областей науки, техники, технологий, творческих областей [4].

Метод проектов предлагает следующие принципы проведения: а) тема проекта выбирается самим обучающимся; б) студент использует свои собственные источники информации и проводит самостоятельное исследование; в) обучающийся представляет конечный продукт в виде доклада или презентации; г) подготовка проекта занимает продолжительный отрезок времени; д) проект должен иметь личностно-деятельностный характер, ориентированный на удовлетворение интересов обучающихся; е) проект обычно является независимой самостоятельной или командной работой; ж) преподаватель является консультантом, наблюдателем и коммуникатором.

В результате применения проектного метода на занятиях по иностранному языку развиваются познавательные навыки, творческие способности, логическое и критическое мышление, умение адекватно оценивать и извлекать необходимую информацию студентами, навыки коммуникативной деятельности; повышается мотивация к изучению иностранного языка; формируется чувство ответственности, возможность интерпретации и презентации полученных результатов, способность к самостоятельной мыслительной деятельности. Студент приучается к чёткому планированию своих действий, умению работать в команде, повышается его личная уверенность в самореализации и рефлексии.

\section{Заключение}

Таким образом, формирование межкультурной коммуникативной компетенции у студентов-медиков должно быть направлено в первую очередь на повышение мотивации к овладению иностранным языком как средством межкультурного и профессионального взаимодействия. Достижение данной цели возможно путём расширения межкультурного кругозора студентов на основе применения технологий активизации и интенсификации учебной деятельности, что позволяет раскрыть творческие способности студентов, сформировать умение находить решения в различных клинических ситуациях, развить клиническое мышление, самостоятельно приобретать знания, максимально приближенные к практическому здравоохранению [5].

\section{Список литературы}

1. Мартынова М.А. Сущность и структура готовности студентов медицинского вуза к межкультурному взаимодействию в профессиональной сфере // Современные проблемы науки и образования. 2017. № 5. [Электронный pecypc]. URL: https://science- 
education.ru/ru/article/view?id=26755 (дата обращения: 28.01.2021).

2. Макушева Ж.Н. Структурность внеучебного воспитательного мероприятия по дисциплине «Иностранный язык» в медицинском университете // Современные проблемы науки и образования. 2019. № 3. [Электронный ресурc]. URL: URL: http://www.scienceeducation.ru/ru/article/view?id=28875 (дата обращения: 06.02.2021). DOI:10.17513/spno.28875. 3. Ляпина О.А., Рогачева Н.А., Яковлев К.В. Использование игровых технологий при обучении химии // Современные проблемы науки и образования. 2018. № 4. [Электронный pecypc]. URL: http://science-education.ru/ru/article/view?id=27770 (дата обращения: 27.01.2021). 4. Новые педагогические и информационные технологии в системе образования / Под ред. Е. С. Полат. М.: Издательский центр «Академия», 1999. 224 с.

5. Старикова И.В., Алешина Н.Ф., Триголос Н.Н., Попова А.Н., Крайнов С.В., Рукавишникова Л.И., Чаплиева Е.М. Использование ролевых игр в процессе обучения студентов-стоматологов // Современные проблемы науки и образования. 2015. № 3. [Электронный pecypc]. URL: http://science-education.ru/ru/article/view?id=19821 (дата обращения: 27.01.2021). 